Online usage and access logs are now available for our first few months of operation and show a steady and impressive rate of usage, particularly in the past four months.

We hope to add a section on the Northern Ireland peace process to this item. In the future wholly new items which we are considering include the televising of court proceedings (as illustrated by cases such as OJ Simpson and Louise Woodward) and miscarriages of justice.

One important development is that we have reached an agreement with the Incorporated Council of Law Reporting whereby they have allowed us to put up to 25 full case reports on our site. They have agreed to waive their normal copyright fee in recognition of the public service nature of our project. In return, we have agreed to carry an advertisement on each case report. The reporting of cases in this way will provide a major boost to interest in UK Law Online. Case reports (aside from those now emerging from the Court of Appeal and House of Lords) are not readily available (except for payment via LEXIS). We obviously wish to select important but accessible cases, and the first two to appear (with added pictures) have been Carlill v Carbolic Smoke Ball Co and Donoghue v Stevenson.

One other area which has been written concerns the Hamlyn Trust itself. We have described the Trust and also have publicised the Hamlyn Lectures.

\section{THE FUTURE}

Our main task for the future (from October 1998) is to seek further sponsorship of the pages to be able to continue with the intended agenda. Likely sponsors include law firms or legal publishers as well as computing equipment manufacturers. More generally, we are very willing to find a place for suitable 'donations' from guest writers.

Despite the modest nature of our achievements to date, we feel that we have indeed served the general public in accordance with Miss Hamlyn's wishes. In more modern language, it is important to note that we have become 'legal information engineers' in the service of democratic empowerment rather than commercial niche-marketing. As academic lawyers, we have found this pioneering and proselytising project to be worthwhile and exciting and are confident that our browsers have likewise derived - and will continue to derive - considerable benefit and interest from our work.

\section{FURTHER DETAILS}

For further information about this project, please contact Professor Clive Walker, Centre for Criminal Justice Studies, University of Leeds, Leeds LS2 9JT (Tel: 0113233 5033) (http://wnw.leeds.ac.uk/law/hamlyn/)

\title{
Information technology for advising citizens
}

\section{Report by Coatbridge Citizens Advice Bureau}

$\mathrm{C}$ itizens Advice bureaux throughout the UK attempt to ensure that individuals do not suffer either through ignorance of their rights and responsibilities or of the services available to them, or through inability to express their needs effectively. They also aim to exercise a responsible influence on the development of social policies and services both locally and nationally.

\section{on the internet}

http://www.nacab.org.uk

The National Association of Citizens Advice Bureaux website provides a directory of bureaux, links to other sites of interest and a variety of information on current social policy issues.

and print an enquiry record in the presence of each client and provide them with a copy of this record. The system will also provide the means to calculate the welfare benefits to which a client is entitled, and generally provide a print-out of relevant legal and other useful information. There will be a library of standard draft letters, such as the standard 'letters before action' in the small claims court, and appeal letters to the Benefits Agency, for the use of clients. All such material can be printed out and given to clients without delay.

The employment of appropriate information technology to process legal advice and assistance in ways such as those briefly described above will ensure that the scope, type and quality of the information provided will enhance the twin aims of citizens advice bureaux. The pilot project being

Coatbridge $C A B$ was established in 1983 , and its 24 voluntary advisers currently deal with more than 8,000 enquiries annually. The Bureau has recently moved into new premises, and the grant from the Hamlyn Trust was designed to assist with the creation and testing of a pilot scheme in the use of computers in each interview room, with a view to improving the standard of advice and assistance given to clients. This project is being undertaken in conjunction with the Scottish Association of Citizens Advice Bureaux as part of a general programme to computerise the information system which all Bureaux currently use.

Completion of the project will make Coatbridge the first $\mathrm{CAB}$ to integrate contemporary information technology into the task of providing legal advice. The grant has been used to purchase four computers, a printer and appropriate networking facilities. Software provided by SACAB will allow bureau advisors to write undertaken at Coatbridge is intended to act as an example for other Citizens Advice Bureaux in Scotland and elsewhere in the $\mathrm{UK}$, and the lessons learned from this experiment will benefit other bureaux as they develop their own information technology strategies.

$$
\text { (c) }
$$

\section{FURTHER DETAILS}

Further information concerning this project may be obtained from Mr Jim Melvin, Bureau Manager, Coatbridge CAB, Fountain Business Centre, Ellis St, Coatbridge, Scotland ML5 3AA (Tel: 01236 42 1447) 